\title{
SINTESIS DAN STUDI IN SILICO SENYAWA 3-NITRO-N'-[(PYRIDIN-4-YL) CARBONYL]BENZOHYDRAZIDE SEBAGAI KANDIDAT ANTITUBERKULOSIS
}

\author{
Ruswanto $^{\mathrm{a}^{*}, \text { Mardhiah }^{\mathrm{a}}, \text { Richa Mardianingrum }^{\mathrm{a}} \& \text { Korry Novitriani }}{ }^{\mathrm{a}}$ \\ ${ }^{a}$ Prodi Farmasi, STIKes Bakti Tunas Husada, Jl. Cilolohan No. 36 Tasikmalaya \\ *Alamat Korespondensi: Jl. Sukanaga Sindanggalih RT. 001 RW. 015 Kel. Kahuripan Kec. Tawang
}

\begin{abstract}
Abstrak: InhA adalah enoyl-acyl carrier protein reductase didalam Mycobacterium tuberculosis yang merupakan target yang menarik untuk pengembangan obat baru terhadap TBC, penyakit yang membunuh lebih dari dua juta orang setiap tahun. InhA adalah target utama obat isoniazid dalam pengobatan infeksi tuberkulosis. Pada penelitian ini telah disintesis turunan isoniazid yaitu senyawa 3-nitro- $N^{\prime}$ - $[($ pyridin-4yl)carbonyl]benzohydrazide melalui reaksi asilasi antara 3-nitrobenzoil klorida dengan isoniazid dengan menggunakan pelarut tetrahidrofuran. Persentase hasil sintesis adalah 59,11\%. Kemurnian hasil sintesis ditunjukkan dengan adanya noda tunggal pada KLT (Komatografi lapis tipis) dan jarak lebur yang sempit. Berdasarkan hasil identifikasi Spektrofotometer UV, Spektrofotometer IR dan Spektrometer ${ }^{1} \mathrm{H}-\mathrm{NMR}$ menunjukkan senyawa hasil sintesis 3-nitro- $N^{\prime}-[($ pyridin-4-yl)carbonyl]benzohydrazide sesuai dengan yang diharapkan. Selain itu dalam penelitian ini juga dilakukan uji in silico: (1) Uji toksisitas dilakukan dengan menggunakan tiga parameter seperti benigni, crammer rules dan kroes TTC, (2) Interaksi senyawa 3-nitro- $N^{\prime}-$ [(pyridin-4-yl)carbonyl]benzohydrazide terhadap InhA yang menunjukkan bahwa 3-nitro- $N^{\prime}-[($ pyridin-4yl)carbonyl] benzohydrazide memiliki interaksi dengan reseptor enoyl-acyl carrier protein reductase (InhA) lebih baik daripada isoniazid dengan nilai binding affinity 3-nitro-N'-[(pyridin-4-yl)carbonyl]benzohydrazide sebesar $-9,17647 \mathrm{kkal} / \mathrm{mol}$ dan isoniazid $-7,1034 \mathrm{kkal} / \mathrm{mol}$.
\end{abstract}

Kata kunci: isoniazid, tuberkulosis, InhA, benzohydrazide

\begin{abstract}
InhA, the enoyl-ACP reductase in Mycobacterium tuberculosis is an attractive target for the development of novel drugs against tuberculosis, a disease that kills more than two million people each year. InhA is the target of the current first line drug isoniazid for the treatment of tuberculosis infections. The 3-nitro$N^{\prime}$-[(pyridin-4-yl)carbonyl]benzohydrazide compound has been synthesized by asilation reaction 3-nitrobenzoyl chloride with Isonicotinohydrazide using tetrahidrofuran solvent. The percentage outcome synthesis was 59,11\%. The purity shown by single stain on TLC (Thin Layer Chromatography) and narrow melting distance. Based on the identification result of UV Spectrofotometer, Infrared Spectrofotometer and H-NMR Spectrometer, the synthesis result compound was sign similarity as expected. In addition, this study also tested in silico: (1) Toxicity test conducted using three parameters likes benigni, crammer rulles and kroes TTC, (2) The interaction study of 3-nitro- $N^{\prime}-[($ pyridin-4-yl)carbonyl]benzohydrazide compound with enoyl-acyl carrier protein reductase (InhA) better than isoniazid with binding affinity value $-9.17647 \mathrm{kcal} /$ and $-7.1034 \mathrm{kcal} / \mathrm{mol}$ for isoniazid.
\end{abstract}

Keywords: isoniazid, tuberculosis, InhA, benzohydrazide

\section{PENDAHULUAN}

Tuberkulosis (TB) menjadi penyakit yang sangat diperhitungkan saat meningkatnya angka kematian penduduk terutama di negara berkembang. Diperkirakan sepertiga populasi dunia terinfeksi Mycobacterium tuberculosis, organisme penyebab tuberculosis (Somantri, 2007).

Secara nasional, pada tahun 2004 ada 539.000 kasus baru dan kematian 101 per 100.000 penduduk. Dari laporan Wolrd Health Organization (WHO) tahun 2005 dinyatakan bahwa estimasi insiden TB paru di indonesia dengan dasar hasil pemeriksaan dahak bakteri tahan asam (BTA) positif adalah 128 per 100.000 penduduk. Sedangkan estimasi TB paru semua kasus adalah 675 per 100.000 penduduk untuk tahun 2003 dengan perkiraan prevalensi sebesar 295 per 100.000 penduduk (Widyanto dkk., 2013). Survei yang dilakukan WHO tahun 2007 menunjukan adanya 92 juta kasus baru dan 1,8 juta jiwa diantaranya meninggal dunia. Indonesia menduduki peringkat ketiga didunia setelah Cina dan India dalam jumlah kasus TB (Barker etal., 2009).

Banyaknya kasus baru dan kematian ini merupakan salah satu akibat dari terjadinya resistensi Mycobacterium tuberculosis terhadap isoniazid. Isoniazid merupakan suatu prodrug yang akan diaktivasi oleh KatG (Katalase-peroksidase). Isoniazid juga merupakan obat tuberkulosis yang paling penting saat ini. Penelitian mengenai resistensi kuman tersebut terhadap Isoniazid di Yogyakarta mencapai 16\% (Rintiswati \& Wijayanti, 1999). Resistensi Mycobacterium tuberculosis memacu perkembangan penelitian obat antituberkulosis.

Beberapa penelitian terbaru telah mengembangkan senyawa-senyawa ester yang dapat digunakan dalam pengobatan TB yang menunjukan bahwa senyawa ester yang disintesis memperlihatkan aktivitas antituberkulosis yang menarik dengan 
konsentrasi daya hambat sekitar $\geq 90 \%$ (Firdaus dkk., 2013). Telah disintesis beberapa derivat baru dari (E)-N-(monosubstituted-benzylidene) isonicotino hydrazide- dan 2-propoxybenzylideneisonicotino hydrazide. Derivat dari (E)-N-(monosubstitutedbenzyli-dene)isonicotinohydrazide secara signifikan mampu menghambat aktivitas Mycobacterium tuberculosis denganMinimum Inhibitory Concentration (MIC) sebesar $0,31 \mu \mathrm{g} / \mathrm{mL}$ (Lourenco etal., 2007). Malhotra, etal (2011) telah mensintesis dan mengevaluasi beberapa derivat baru dari 2propoxybenzyli- deneisonicotinihydrazide sebagai senyawa anti bakteri. Senyawa 2propoxybenzylideneisonico tinihydrazide merupakan hasil reaksi antara isoniazid dengan 2propoxybenzaldehyde menggunakan pelarut etanol. Kemudian, 2-propoxybenzylideneisonicotinohydra zide dievaluasi menggunakan metode elemental dan spektral.

Pada penelitian telah berhasil direaksikan antara isoniazid dengan 3-nitrobenzoyl klorida menghasilkan 3-nitro- $N^{\prime}-[($ pyridin-4-yl)carbonyl] benzohydrazide. Penambahan gugus aromatik akan menambah sifat non polarnya sehingga akan meningkatkan sifat lipofilitasnya. Dengan meningkatnya sifat lipofilitas ini, maka diharapkan obat akan lebih mudah masuk ke dalam membran inti. Selain itu pada struktur tersebut terdapat gugusgugus yang bersifat hidrofil. Gugus hidrofil ini berhubungan dengan kelarutan senyawa dalam cairan luar sel yang berhubungan dengan proses transpor obat ke tempat aksi atau reseptor.

Selain sintesis, penelitian ini juga bertujuan secara in silico untuk mempelajari interaksi senyawa 3-nitro- $N$ '-[(pyridin-4-yl)carbonyl] benzohydrazide dengan reseptor InhA melalui metode docking, mempelajari prediksi toksisitas dengan Toxtree dan drug scans dari Lipinski.

\section{BAHAN DAN METODE Alat}

Alat yang digunakan untuk sintesis diantaranya peralatan gelas yang sederhana, magnetic stirrer, hot plate, rotary evaporator, corong buchner, lampu UV $254 \mathrm{~nm}$, chamber, oven, kertas saring, timbangan analitik, gelas ukur, corong pisah, alat refluks, botol semprot, gelas kimia, pipet tetes, termometer, Electrothermal Melting Point 9100, Spektrofotometer UV-Visibel SHIMADZU 1240, Spektrometer Massa, Spektrometer Infra merah, spektrometer ${ }^{1} \mathrm{H}-\mathrm{NMR}$ dan spektrometer ${ }^{13} \mathrm{C}-\mathrm{NMR}$. Sedangkan alat yang digunakan untuk studi in silico diantaranya komputer dengan processor AMD Athlon (Neo) X2 Dual Core Processor L335 1,60 GHz dengan kapasitas memori 2,00 GB dan software yang dignakan adalah Marvin Sketch 5.2, ArgusLab, MMV (Molegro Molecular Viewer) dan ToxTree.

\section{Bahan}

Bahan-bahan yang digunakan untuk sintesis yaitu Isoniazid, 3-Nitrobenzoil klorida, tetrahidrofuran p.a , trietilamin p.a, etanol p.a, Natrium Bikarbonat p.a, aquabidestillata, kloroform p.a, Silika gel $60 \mathrm{GF}_{254}$. Sedangkan bahan-bahan yang digunakan untuk studi in silico diantaranya reseptor InhA yang didownload dari Protein Data Bank (PDB).

\section{Sintesis 3-nitro- $N^{\prime}-[($ pyridin-4-yl)carbonyl] benzo- hydrazide}

Isoniazid ditimbang sebanyak $10 \mathrm{mmol}$ pada timbangan analitik kemudian dimasukan ke dalam labu alas datar yang kering lalu ditambah $15 \mathrm{~mL}$ tetrahidrofuran dan $3 \mathrm{~mL}$ trietilamin ke dalam labu alas datar tersebut. Lalu pada corong pisah kering masukan 5 mmol 3-Nitrobenzoyl klorida dan $15 \mathrm{~mL}$ tetrahidrofuran kocok secara perlahan. Kemudian teteskan sedikit demi sedikit ke dalam labu sambil diaduk dengan menggunakan magnetic stirrer pada suhu kamar sampai habis. Selanjutnya campuran direfluks pada suhu $\pm 80-150{ }^{\circ} \mathrm{C}$ dan diaduk dengan magnetic stirrer. Setiap jam hasil reaksi di dalam labu diuji KLT dengan menggunakan eluen etanol : kloroform dengan perbandingan $8: 1$ sampai didapat hasil satu spot. Selanjutnya hasil refluks diuapkan menggunakan rotary evaporator sampai kental. Setelah itu ditambah natrium bikarbonat jenuh secukupnya untuk menghilangkan hasil samping $\mathrm{HCl}$ yang terbentuk sampai tidak keluar buih lagi. Lalu dicuci dengan aquadest secukupnya kemudian disaring dengan corong Buchner (Suzzana, 2010).

\section{Rekristalisasi}

Etanol absolut sebanyak 50-100 mL dimasukan ke dalam gelas kimia $100 \mathrm{~mL}$ kemudian dipanaskan pada hot plate. Setelah mendidih senyawa hasil sintesis dimasukan ke dalam larutan etanol panas sampai semua larut dan dihentikan pemanasan sampai pelarut tersisa setengahnya. Larutan yang diperoleh didiamkan pada suhu kamar sampai terbentuk kristal. Setelah itu kristal yang terbentuk disaring dengan corong buchner lalu dipindahkan ke cawan uap dan dikeringkan pada suhu $60{ }^{\circ} \mathrm{C}$ selama 30-60 menit kemudian kristal ditimbang (Suzzana, 2010).

\section{Uji kemurnian}

Untuk mengetahui kemurnian senyawa hasil sintesis dilakukan dengan cara KLT, digunakan fasa diam silika gel $60 \mathrm{GF}_{254}$ dan fase gerak $1=$ metanol : kloroform $(9: 1)$, fase gerak $2=$ metanol : etil asetat (3:1), dan fase gerak $3=$ etanol $: N$-heksan $(3: 1)$. Setelah dielusi dikeringkan, dilihat nodanya pada lampu UV kemudian ditentukan Rf sampel dan dibandingkan $\mathrm{Rf}$ pembanding. Noda tunggal yang timbul pada berbagai sistem fase gerak menunjukkan senyawa murni secara KLT. Uji kemurnian dilakukan juga dengan pengujian melting point. 


\section{Identifikasi dan Karakterisasi Struktur}

Identifikasi dan karakteristik senyawa hasil sintesis dilakukan dengan menggunakan Spektrofotometer UV-Visibel, Spektrometer Inframerah, ${ }^{1} \mathrm{H}-\mathrm{NMR}$ dan Spektrometer Massa untuk mengetahui struktur senyawa hasil sintesis (Silverstein, 1998).

\section{Docking}

Senyawa 3-nitro-N'-[(pyridin-4-yl)carbonyl $]$ benzohydrazide dan pembanding isoniazid didocking-kan pada reseptor enoyl-acyl carrier protein reductase dengan menggunakan metode ArgusDock dengan software ArgusLab melalui beberapa tahapan.

\section{Preparasi Senyawa}

Senyawa digambar dengan menggunakan software marvin sketch 5.2 lalu dioptimasi geometri, dengan diprotonasi pada $\mathrm{pH} 7,4$ agar $\mathrm{pH}$ sesuai dengan $\mathrm{pH}$ dalam darah. Kemudian dilakukan Conformation search ini dilakukan untuk memperoleh energi yang terendah sehingga didapatkan posisi molekul yang paling stabil untuk berinteraksi dengan sisi aktif reseptor. Kemudian disimpan dalam bentuk .mrv dan .mol2 untuk proses docking.

\section{Validasi Metode Docking}

Program ArgusLab divalidasi untuk mendapat metode yang dapat dipercaya. Reseptor yang digunakan adalah reseptor Inha yang diperoleh dari Protein Data Bank (PDB). Protein reseptor yang telah didownload ini kemudian dipilih senyawa alaminya untuk proses validasi metode docking. Parameter yang diperoleh apabila metodenya valid adalah RMSD position between two simlliar groups. Metode docking dikatakan baik jika nilai RMSD yang dihasilkan lebih kecil atau sama dengan 2. Jika nilai RMSD yang diperoleh lebih besar dari $2 \AA$ maka metode yang digunakan tidak dapat dipercaya (Thompson, 2004).

Hasil yang diperoleh dari proses docking ini adalah berupa energy best senyawad pose atau berupa binding affinity senyawa/senyawa. Selanjutnya dari proses docking dapat dilihat interaksi antara senyawa dengan sisi aktif reseptor menggunakan software LigPlot (Wardani, 2012).

\section{Screening Senyawa Based Drugs Likeness (Drugs scan)}

Pengamatan obat dilakukan dengan memperhatikan the rule of good medicine (Lipinski's rule of five) dan Bioavailabilitas oral dari senyawa. Parameter yang digunakan yaitu berat molekul $<500$ $\mathrm{g} / \mathrm{mol}$, lipofilitas $<5$, donor ikatan hidrogen $<5$, aseptor ikatan hidrogen $<10$, dan refractory molar antara 40-130 (Lipinski etal, 1997). Parameter tersebut dapat dilihat dengan bantuan program MarvinSketch 5.2.

\section{Uji toksisitas}

Uji toksisitas dilakukan terhadap senyawa Senyawa 3-nitro- $N^{\prime}-[($ pyridin-4-yl)carbonyl] benzohydrazide dengan menggunakan software ToxTree. Parameter yang dilihat pada uji toksisitas ini adalah prediksi parameter Cramer Rules, Kroes TTC decision tree dan Benigni / Bossa rulebase (Harganingtiyas, 2012). Cramer Rules digunakan untuk melihat tingkatan toksisitas dilihat dari gugus fungsinya.Kroes TTC decision tree untuk memperkirakan ambang batas paparan senyawa obat pada manusiadan Benigni / Bossa rulebase untuk mengetahui apa senyawa tersebut dapat menyebabkan karsinogenisitas dan mutagenisitas.

\section{HASIL DAN PEMBAHASAN}

Dari hasil sintesis selama 8 jam senyawa 3-nitro$N^{\prime}$-[(pyridin-4-yl)carbonyl]benzohydrazide diperoleh sebanyak 1,35 gram dengan presentase hasil yang didapat adalah 59,11\%. Senyawa hasil sintesis berbentuk serbuk, berwarna kuning, baunya khas, tidak larut dalam air, sedikit larut dalam etanol dingin, larut dalam etanol panas

\section{Uji Kemurnian}

Uji kemurnian senyawa hasil sintesis dilakukan dengan uji KLT menggunakan beberapa eluen yang berbeda polaritasnya. Dapat dilihat pada tabel 1.

Tabel 1. Hasil Uji Kemurnian dengan KLT

\begin{tabular}{cccc}
\hline Fase gerak & Replikasi & $\begin{array}{c}\mathrm{Rf} \\
\text { hasil } \\
\text { sintesis }\end{array}$ & $\begin{array}{c}\mathrm{Rf} \\
\text { Isoniazid }\end{array}$ \\
\hline Metanol : & 1 & 0,67 & 0,52 \\
kloroform & 2 & 0,67 & 0,52 \\
$(9: 1)$ & 3 & 0,63 & 0,52 \\
Metanol : & 1 & 0,72 & 0,55 \\
Etil asetat & 2 & 0,71 & 0,55 \\
$(3: 1)$ & 3 & 0,66 & 0,55 \\
Etanol : $N$ - & 1 & 0,65 & 0,53 \\
heksan & 2 & 0,65 & 0,53 \\
$(3: 1)$ & 3 & 0,77 & 0,53 \\
\hline
\end{tabular}

Eluen metanol, etil asetat, kloroform dan nheksan digunakan sebagi eluen. Hal ini ditujukan untuk menghasilkan kepolaran yang berbeda-beda, dimana campuran pelarut metanol dan kloroform merupakan eluen yang paling polar diantara yang lainnya.Uji kemurnian selanjutnya dilakukan dengan menguji jarak lebur senyawa hasil sintesis menggunakan alat Electrothermal 9100. Suatu senyawa dikatakan murni apabila selisih antara suhu lebur senyawa mulai melebur dengan suhu senyawa melebur seluruhnya adalah $2^{\circ} \mathrm{C}$. Dari hasil uji di dapat titik lebur dari senyawa 3-nitro- $N^{\prime}-[$ (pyridin-4yl)carbonyl]benzohydrazide yaitu $194,5-195,7^{\circ} \mathrm{C}$. Titik lebur ini berbeda dengan titik lebur dari isoniazid (171-173 $\left.{ }^{\circ} \mathrm{C}\right)$ dan 3-nitrobenzoil klorida (275-278 $\left.{ }^{\circ} \mathrm{C}\right)$. 


\section{Identifikasi dan Karakterisasi Struktur}

Identifikasi dan karakterisasi dari senyawa hasil sintesis dilakukan dengan menggunakan Spektrofotometri Ultraviolet, Spektrofotometri Infra merah, Spektrometri Resonansi Magnet Proton $\left({ }^{1} \mathrm{H}\right.$ NMR) dan Spektrometri Massa.

Identifikasi dan karakterisasi di awali dengan spektrofotometri UV-Vis. Pada spektrofotometri UVVis didapatkan panjang gelombang maksimum senyawa hasil sintesis yaitu ada pada panjang gelombang 365,5 nm. Panjang gelombang ini berbeda dari panjang gelombang maksimum isoniazid yaitu $265,0 \mathrm{~nm}$.

Panjang gelombang senyawa hasil sintesis lebih besar daripada panjang gelombang isoniazid. Hal ini terjadi karena terjadinya suatu efek batokromik (pergeseran merah). Batokromik merupakan suatu pergeseran panjang gelombang maksimal ke arah panjang gelombang yang lebih panjang (Gholib, 2013). Efek ini terlihat apabila panjang sistem terkonjugasi bertambah. Selain itu efek ini juga terlihat bila sistem terkonjugasi disubstitusi dengan berbagai gugus (Creswell, 2005).

Selanjutnya identifikasi dilakukan dengan spektrofotometri Infra Merah. Spektrofotometri Infra Merah memberikan gambaran tentang gugus-gugus fungsi yang ada pada molekul hasil senyawa sintesis. Berdasarkan hasil identifikasi dengan spektrofotometri Infra merah diperoleh bilangan gelombang spektrum Infra Merah seperti pada tabel 4.2.

Tabel 2. Bilangan spektrum infra merah

\begin{tabular}{cc}
\hline $\begin{array}{c}\text { Gugus fungsi/ jenis } \\
\text { ikatan }\end{array}$ & Bilangan Gelombang $\left(\mathbf{c m}^{-\mathbf{1}}\right)$ \\
\hline Ulur $-\mathrm{NH}$ & 3220,54 \\
Ulur C=O & 1646,91 \\
- C=C- aromatis & 1531,2 \\
& 1349,93 \\
Aromatis disubstitusi & 856,239 \\
& 713,533 \\
& 593,965 \\
\hline
\end{tabular}

Dari tabel di atas, dapat dilihat beberapa puncak bilangan gelombang yang berasal dari gugus-gugus penting pada molekul senyawa 3-nitro- $N^{\prime}-[$ (pyridin4-yl)carbonyl] benzohydrazide. Berdasarkan spektrum di atas gugus yang teridentifikasi antara lain $\mathrm{C}=\mathrm{O}$ amida $\left(1646,91 \mathrm{~cm}^{-1}\right)$, ikatan $\mathrm{N}-\mathrm{H}(3220,54$ $\left.\mathrm{cm}^{-1}\right)$, ikatan $\mathrm{C}=\mathrm{C}$ aromatic $\left(1531,2\right.$ dan $\left.1349,93 \mathrm{~cm}^{-1}\right)$.

Identifikasi struktur dilanjutkan dengan menggunakan spektroskopi ${ }^{1} \mathrm{H}-\mathrm{NMR}$. Spektroskopi ${ }^{1} \mathrm{H}-\mathrm{NMR}$ digunakan untuk mengetahui informasi tentang jenis hidrogen, jumlah hidrogen dan lingkungan hidrogen dalam suatu senyawa (Cresswell, 2005). Spektrum ${ }^{1} \mathrm{H}-\mathrm{NMR}$ adalah grafik dari banyaknya energi yang diserap versus kuat medan magnet (Cresswell, 2005). Pada spektrum ${ }^{1} \mathrm{H}$ NMR yang dilihat adalah nilai geseran kimia. Berdasarkan spektrum di atas maka dapat dilihat beberapa pergeseran kimia dan multiplisitas yang dihasilkan di jelaskan dalam tabel 3.

Tabel 3. Hasil Analisis Spektrofotometri ${ }^{1} \mathrm{H}-\mathrm{NMR}$

\begin{tabular}{ccc}
\hline $\begin{array}{c}\text { Pergeseran } \\
\text { kimia(ppm) }\end{array}$ & Multiplisitas & Atom H dari gugus \\
\hline $7,727-7,756$ & Triplet & Satu atom H \\
$8,036-8,045$ & Doublet & Dua atom H \\
$8,459-8,474$ & Doublet & Dua atom H \\
$8,536-8,549$ & Doublet & Satu atom H \\
& Singlet & Satu atom H dari \\
8,760 & gugus - NH \\
$8,839-8,848$ & Doublet & Satu atom H \\
$8,889-8,898$ & Doublet & Dua atom H \\
\hline
\end{tabular}

Identifikasi dilanjutkan dengan spektrometri Massa. Hasil identifikasi dapat dilihat pada gambar 1.

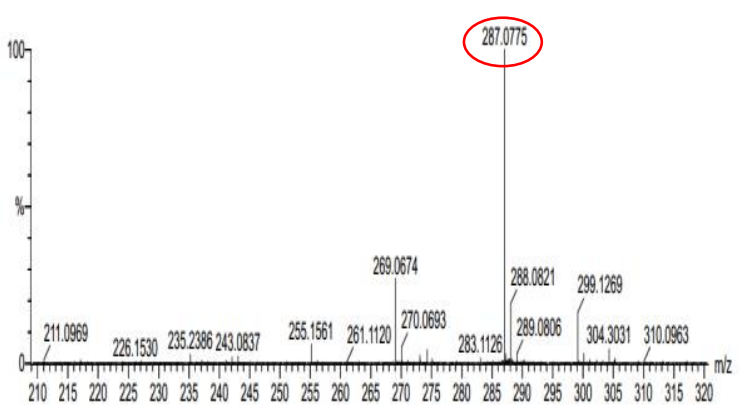

Gambar 1. Hasil Spektrum MS senyawa 3-nitro- $N$ '[(pyridin-4-yl)carbonyl] benzohydrazide

Dari spektrum spektrometri massa memperkuat dugaan bahwa hasil senyawa sintesis merupakan senyawa 3-nitro- $N^{\prime}-[($ pyridin-4-yl)carbonyl] benzo hydrazide. Berat molekul yang terlihat pada spektrum dibandingkan dengan berat molekul dari perhitungan menggunakan software Chem Draw. Hasilnya, didapat berat molekul 286,07.

Berdasarkan hasil spektrum massa terlihat puncak tertinggi ion molekul dari BM senyawa Hasil Sintesis. Dengan demikian terbukti bahwa senyawa hasil sintesis telah terbentuk dari proses sintesis jika dilihat dari beberapa hasil identifikasi.

\section{Docking}

Proses docking menggunakan program ArgusLab. Reseptor yang digunakan adalah enoylacyl carrier protein reductase (Kode PDB 2X23) dan senyawa alaminya yaitu TCU dan pembanding isoniazid (struktur pada gambar 2). Pada proses validasi ini digunakan 2 docking engine yaitu ArgusDock dan GADock. ArgusDock hanya memperhitungkan posisi tertentu/terarah dengan pendekatan strukturnya, sehingga hasil yang diperoleh bersifat reprodusible. Sedangkan GADock memperhitungkan berbagai kemungkinan posisi yang ada sehingga hasil yang didapatkan tidak tetap (non 
reproducible). Validasi dengan 2 docking engine ini dilakukan pada keadaan tanpa air pada reseptor karena keberadaan air dapat mempengaruhi interaksi ikatan senyawad-reseptor. Pada proses validasi ini nilai yang dilihat adalah nilai Root Mean Square Deviation (RMSD).<smiles>NNC(=O)c1ccncc1</smiles>

(a)

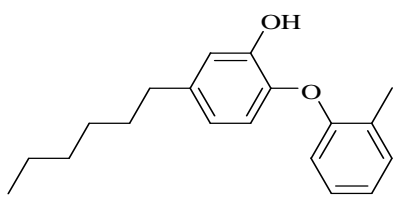

(c)

Gambar 2. Struktur Kimia: (a) Isoniazid, (b) 3-nitro$N^{\prime}-[($ pyridin-4-yl)carbonyl] benzohydra-zide, dan (c) TCU

Grid box yang digunakan pada proses docking yaitu X : 11,25, Y : 20,75, Z : 12,25 angstrom. Nilai RMSD yang didapat dengan menggunakan docking engine ArgusDock adalah sebesar 1,37 ̊. Sehingga pada penelitian ini digunakan docking engine ArgusDock karena nilai RMSD nya $\leq 2$ yang menandakan bahwa metode yang digunakan reliable. Selain itu jika menggunakan ArgusDock hasil yang diperoleh bersifat reprodusible.

Berdasarkan hasil docking antara senyawa dengan reseptor diperoleh konformasi senyawa dengan energi terkecil. Binding affinity merupakan ukuran kemampuan obat untuk berikatan pada reseptor. Ikatan kovalen menghasilkan afinitas kuat, interaksi stabil dan ireversibel. Ikatan elektrostatik bisa menghasilkan afinitas kuat atau lemah, biasanya bersifat reversibel. Semakin kecil nilai binding Affinity maka afinitas antara reseptor dengan senyawa semakin tinggi begitu pula sebaliknya semakin besar nilai binding Affinity maka afinitas antara reseptor dengan senyawa semakin rendah. Nilai binding afinitas senyawa 3-nitro- $N^{\prime}$-[(pyridin-4-yl)carbonyl] benzo hydrazide dapat dilihat pada tabel 4 . Nilai ini kemudian dibandingkan terhadap senyawa alami (TCU) dan obat isoniazid.

Berdasarkan hasil docking nilai binding affinty senyawa 3-nitro- $N$ '-[(pyridin-4-yl)carbonyl]benzo hydrazide adalah $-9,18$. Nilai ini lebih besar daripada binding affinity TCU. Tetapi dibandingkan dengan isoniazid senyawa 3-nitro- $N^{\prime}-[$ (pyridin-4- yl)carbonyl] benzohydrazide mempunyai interaksi yang lebih baik terhadap reseptor InhA sehingga berpotensi digunakan sebagai kandidat lead compound obat anti tuberkulosis.

Tabel 4. Perbandingan Nilai Binding Affinity $(\Delta \mathrm{G})$ Senyawa 3-nitro- $N$ - $[($ pyridin-4-yl) carbonyl $]$ benzo hydrazide, TCU dan Isoniazid

\begin{tabular}{cccc}
\hline & $\begin{array}{c}\Delta \mathrm{G} \\
\text { 3-nitro- } N^{\prime}-\end{array}$ & & \\
Reseptor & $\begin{array}{c}\text { [(pyridin-4- } \\
\text { yl) } \text { carbonyl }] \\
\text { benzo } \\
\text { hydrazide } \\
\text { (Kkal/mol) }\end{array}$ & $\begin{array}{c}\Delta \mathrm{G} \\
\mathrm{TCU}\end{array}$ & $\begin{array}{c}\Delta \mathrm{G} \\
\text { Isoniazid } \\
(\mathrm{Kkal} / \mathrm{mol})\end{array}$ \\
$\begin{array}{cccc}(\mathrm{Kkal} / \mathrm{mol}) \\
\text { Inha } \\
\text { (kode }\end{array}$ & $-9,18$ & $-12,76$ & $-7,14$ \\
2X23) & & & \\
\hline
\end{tabular}

\section{Visualisasi Hasil Docking}

Visualisasi hasil docking dilakukan untuk mengetahui interaksi antara senyawa dengan residu asam amino dari reseptor InhA. Adapun interaksi senyawa dapat dilihat pada gambar 3-5.

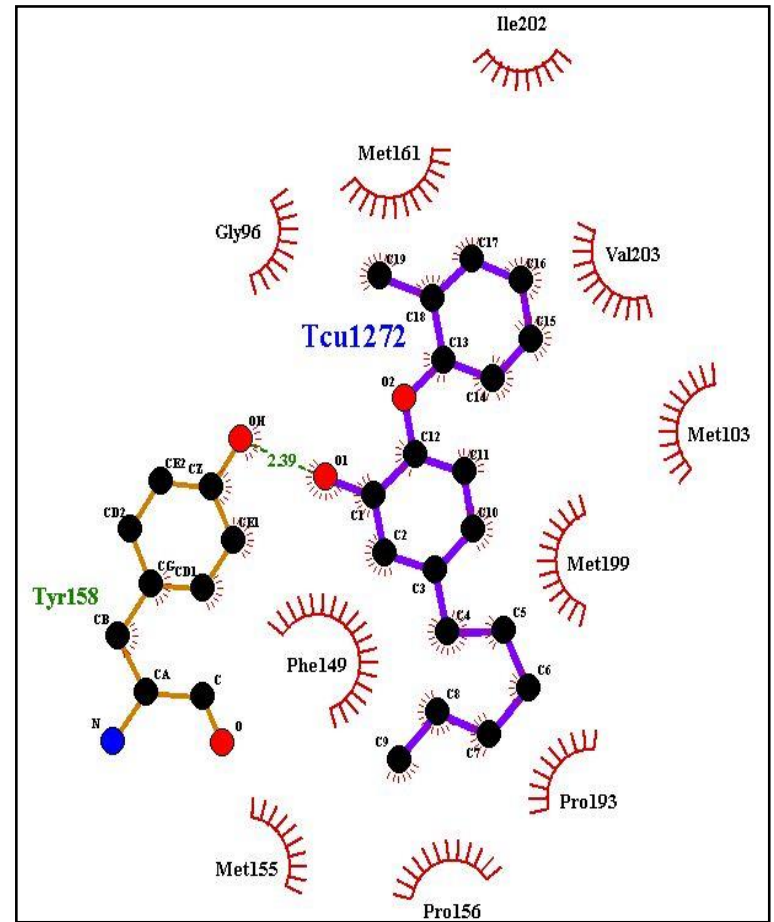

Gambar 3. Interaksi 2D antara TCU dengan InhA

Dari gambar 3 dapat dilihat bahwa interaksi antara TCU dengan reseptor Inha terdapat 1 ikatan hidrogen yaitu dengan residu $\mathrm{Tyr} 158$ dengan besarnya jarak ikatan hidrogen $2,39 \AA$, selain itu ada interaksi hidrofobik (10 residu asam amino) antara TCU dengan Inha.

Dari gambar 4 dapat dilihat bahwa interaksi antara 3nitro-N'-[(pyridin-4-yl)carbonyl]benzo hydrazide 
dengan reseptor Inha terdapat 1 ikatan hidrogen yaitu dengan residu Gln 214 dengan besarnya jarak ikatan hidrogen 2,59 ̊, selain itu ada interaksi hidrofobik (6 residu asam amino) antara senyawa dengan Inha.

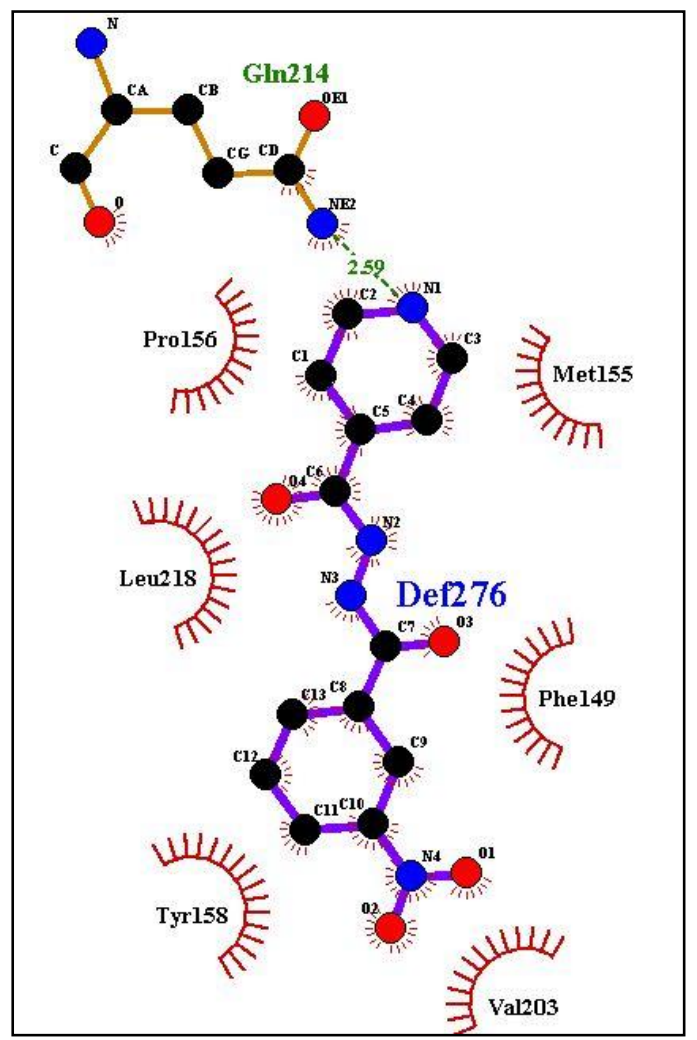

Gambar 4. Interaksi 2D antara 3-nitro- $N^{\prime}-[$ (pyridin-4yl)carbonyl]benzo hydrazide dengan InhA

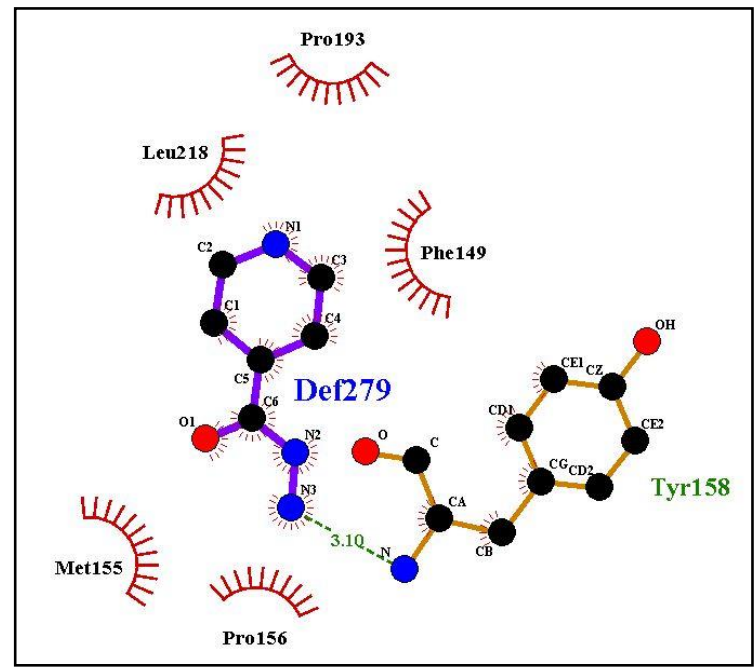

Gambar 5. Interaksi 2D antara Isoniazid dengan InhA

Dari gambar 5 dapat dilihat bahwa interaksi antara isoniazid dengan reseptor Inha terdapat 1 ikatan hidrogen yaitu dengan residu Tyr 158 dengan besarnya jarak ikatan hidrogen $3,10 \AA$, selain itu ada interaksi hidrofobik (5 residu asam amino) antara isoniazid dengan Inha.

\section{Screening Senyawa Based Drugs Likeness (Drugs scan)}

Penerapan aturan lipinski ini berhubungan dengan proses absorpsi atau permeabilitas terhadap lipid bilayer yang ada di dalam tubuh. Jika nilai Log $\mathrm{P}>5$ maka suatu senyawa akan lebih lama tinggal di lipid bilayer dan terdistribusi lebih luas di dalam tubuh sehingga selektivitas ikatan terhadap enzim target menjadi berkurang dan menyebabkan toksisitasnya menjadi lebih tinggi. Jika berat molekul suatu senyawa > 500, artinya senyawa tersebut memiliki ukuran yang besar sehingga proses absorpsi akan semakin lama. Hasilnya dapat dilihat pada tabel 5 .

Tabel 5. Hasil Penapisan Aturan Lipinski

\begin{tabular}{lcc}
\hline \multicolumn{1}{c}{ Parameter } & Nilai & Keterangan \\
\hline $\begin{array}{l}\text { Donor Hidrogen } \\
\text { Akseptor }\end{array}$ & 2 & memenuhi \\
$\begin{array}{l}\text { Hidrogen } \\
\text { Berat Molekul }\end{array}$ & 5 & memenuhi \\
$\begin{array}{l}\text { Refractivity } \\
\text { Molar }\end{array}$ & 286,2429 & memenuhi \\
Log P & 73,84 & memenuhi \\
\hline
\end{tabular}

Berdasarkan data yang diperoleh, diketahui bahwa semua senyawa 3-nitro- $N^{\prime}-[$ (pyridin-4yl)carbonyl] benzo hydrazide memenuhi kelima aturan lipinski, yaitu $\log \mathrm{P}<5$, akseptor hidrogen < 10 , donor hidrogen $<5$, dan berat molekul $<500$, sertarefractivity molar 40-130, artinya senyawa tersebut memiliki absorpsi atau permeabilitas yang baik.

\section{Uji Toksisitas}

Pada uji ini digunakan 3 parameter toksisitas yaitu Cramer Rules untuk melihat tingkatan toksisitas dilihat dari gugus fungsinya, Kroes TTC decision tree untuk memperkirakan ambang batas paparan senyawa obat pada manusia dan Benigni / Bossa rulebase untuk mengetahui apa senyawa tersebut dapat menyebabkan karsinogenisitas dan mutagenisitas. Hasil uji toksisitas dapat dilihat pada tabel 6 .

Berdasarkan parameter Cramer Rule's bahwa senyawa 3-nitro- $N^{\prime}-[($ pyridin-4-yl)carbonyl] benzo hydrazide memiliki toksisitas High (Class III), artinya dengan konsentrasi yang tinggi dari senyawa 3-nitro- $N$--[(pyridin-4-yl)carbonyl]benzo hydrazide tidak dijamin keamanan dalam penggunaannya.Class III menyebutkan bahwasubstansi dari struktur kimia ini dari segi keamannya memberikan pengaruh awal yang tidak terlalu kuat. Tetapi substansi dari struktur kimia ini mungkin memberikan kesan memiliki toksisitas yang cukup berarti. Misalnya substansi heterosiklik dan heteroaromatik dan substansi siklik yang lain, beberapa mempunyai rantai samping dengan gugus fungsional yang reaktif. Uji Cramer Rule's ini berdasarkan gugus fungsi yang dimiliki oleh senyawa 3-nitro- $N^{\prime}-[($ pyridin-4-yl)carbonyl] 
benzohydrazide. Senyawa 3-nitro- $N^{\prime}-[$ (pyridin-4yl)carbonyl]benzo hydrazide memiliki gugus fungsi yang berkontribusi dalam peningkatan toksisitas, yaitu adanya gugus heteroaromatik.

Tabel 6. Hasil Uji Toksisitas Toxtree

\begin{tabular}{|c|c|c|}
\hline Parameter & $\begin{array}{l}\text { 3-nitro- } N^{\prime}- \\
\text { [( pyridin-4- } \\
\text { yl) carbonyl]benzo } \\
\text { hydrazid }\end{array}$ & Isoniazid \\
\hline $\begin{array}{l}\text { Cramer } \\
\text { Rules }\end{array}$ & 3. High (Class III) & $\begin{array}{l}\text { 3. High (Class } \\
\text { III) }\end{array}$ \\
\hline $\begin{array}{l}\text { Kroes TTC } \\
\text { decision } \\
\text { tree }\end{array}$ & $\begin{array}{l}\text { 1. Negligible risk } \\
\text { (low probability } \\
\text { of life-time cancer } \\
\text { risk greater than } \\
1 \text { in } 10^{\wedge} 6 \text { ) }\end{array}$ & $\begin{array}{l}\text { 2. Negligible } \\
\text { risk (low } \\
\text { probability } \\
\text { of life-time } \\
\text { cancer risk } \\
\text { greater than } \\
1 \text { in } 10^{\wedge} 6 \text { ) }\end{array}$ \\
\hline $\begin{array}{l}\text { Benigni / } \\
\text { Bossa } \\
\text { rulebase } \\
\text { (for } \\
\text { mutagenicit } \\
\text { y and } \\
\text { carcinogeni } \\
\text { city) }\end{array}$ & $\begin{array}{l}\text { 3. Structural Alert } \\
\text { for nongenotoxic } \\
\text { carcinogenicity } \\
\text { 9. Negative for } \\
\text { nongenotoxic } \\
\text { carcinogenicity }\end{array}$ & $\begin{array}{l}\text { 2. Structural } \\
\text { Alert for } \\
\text { nongenotoxi } \\
\text { c } \\
\text { carcinogenic } \\
\text { ity } \\
\text { 9. Negative for } \\
\text { nongenotoxic } \\
\text { carcinogenici } \\
\text { ty }\end{array}$ \\
\hline
\end{tabular}

Berdasarkan parameter Kroes TTC decision tree senyawa 3-nitro- $N^{\prime}-[($ pyridin-4-yl)carbonyl] benzohydrazide ambang batas paparan yaitu tidak lebih dari $0,15 \mu \mathrm{g} /$ hari. Ini didasarkan pada analisis data dosis-respon untuk senyawa karsinogenik. Ambang ini memberikan 86-97 \% kemungkinan bahwa beberapa resiko dapat berkurang jika diberikan pada atau di bawah dari $0,15 \mu \mathrm{g} / \mathrm{hari}$ dan senyawa ini menjadi genotoxic carcinogen. Substansi dari struktur kimia ini tidak dianjurkan secara bebas untuk persediaan makanan tetapi cukup untuk menentukan jika substansi ini terdapat di dalam makanan, misalnya sebagai kontaminan.

Sedangkan untuk parameter Benigni / Bossa rulebase senyawa 3-nitro- $N^{\prime}-[($ pyridin-4-yl)carbonyl] benzo hydrazide memiliki struktur yang berkontribusi sebagai obat genotoksik karsinogenik. Salah satu gugus yang berkontribusi yaitu adanya gugus hydrazine yang terdapat pada struktur senyawa 3nitro- $N$ '-[(pyridin-4-yl) carbonyl]benzo hydrazide.

\section{KESIMPULAN}

Dari hasil penelitian dapat disimpulkan bahwa (1) senyawa 3-nitro- $N$--[(pyridin-4-yl)carbonyl] benzo hydrazide dapat disintesis dari reaksi antara 3nitrobenzoil klorida dengan isoniazid, (2) Senyawa 3nitro- $N$ - $[($ pyridin-4-yl) carbonyl] benzo hydrazide mempunyai interaksi dengan reseptor Inha lebih baik daripada pembanding isoniazid dan (3) dari hasil uji in silico (docking, drugs scan, toksisitas) dapat diprediksi senyawa 3-nitro- $N$ '-[(pyridin-4$y l$ carbonyl]benzo hydrazide dapat digunakan sebagai kandidat lead compound obat antituberkulosis yang lebih baik.

\section{Ucapan Terima Kasih}

Ucapan terima kasih diucapkan kepada STIkes Bakti Tunas Husada Tasikmalaya yang telah mengijinkan digunakannya semua fasilitas laboratorium.

\section{DAFTAR PUSTAKA}

Barker, L F, Brennam, J.B, Rosenstein, P.K., \& Sadoff, J C. (2009). Tuberculosis Vaccine Research : the Impact of Immunology. Current Opinion in Immunology, 21 (3), 331-338

Benigni, R., Tcheremenskaia, O., \& Worth, A. (2011). Computational Characterisation of Chemicals and Datasets in Terms of Organic Functional Groups - a New Toxtree Rulebase. JRC Scientific and Technical Reports, EUR $24871: 1$.

Creswell, Clifford J, Olaf A. Runquist, Malcolm M Campbell. (2005). Analisis Spektrum senyawa Organik. Bandung : Penerbit ITB

Firdaus, Ahmad, A. \& Vega, M.C. (2013). Potensi 2Feniletil Pentanoat untuk Meningkatkan Aktivitas Antibiotik InH, Am dan Eta Terhadap Mycobacterium Tuberculosis Strain H37Rv. MANASIR, 1 (1) : 75-82

Harganingtiyas, R. (2011). Modifikasi (1R,2R,3R,5R)-(-)-Isopinocampheylamine sebagai inhibitor M2 proton channel pada Virus Influenza A Subtipe H1N1 Secara In Silico [Skripsi]. Jakarta : Universitas Indonesia.

Lipinski, C.A., Lombardo, F., Dominy, B.W., \& Feeney, P.J., (1997): Experimental and computational approaches to estimate solubility and permeability in drug discovery and development setting, Adv. Drug Del. Rev., 23, 3-26.

Lourenço, M.C.D.S., Ferreira, M.D.L., de Souza, M.V.N., Peralta, M.A., Vasconcelos, T.R.A., \& Henriques, M.D.G.M.O (2007). Synthesis and anti-mycobacterial activity of (E)-N(monosubstituted-benzylidene) isonicotinohydrazyde Derivatives. European Journal of Medicinal Chemistry, 43 (6), 1344-1347.

Malhotra, M., Arora, M., Samad, A., Sahu, K., Phogat, P. \& Deep, A. (2011). Synthesis and Evaluation of Some Novel derivatives of 2Propoxybenzylideneisonicotinohydrazide for Their Potential Antimicrobial activity. Journal of The Serbian Chemical Society. 589-597

Rintiswati N., Wijayanti Y . (1999). Kepekaan M. tuberculosis terhadap Obat Anti Tuberculosis, Berkala Ilmu Kedokteran. 31 : 77-83

Silverstein, R.M., Bassler, G.C., \& Morrill, T.C. (1998). Spectrometric Identification of Organic 
Compound, $4^{\text {th }}$ Ed. New York: John Wiley and Sons Inc.

Somantri, I. (2007). Asuhan Keperawatan pada Pasien dengan Gangguan Sistem Pernapasan. Jakarta : Salemba Medika

Suzana, \& Budiarti, T. ( 2010). Pengaruh Gugus Nitro dengan Posisi Para (p) pada Sintesis N-(4Nitrobenzoil)tiourea. Majalah Farmasi Airlangga, 8 (1), 15-19.
Thompson. (2004). ArgusLab 4.0.1. Planaria Software LLC., Seatle, Wash, USA.

Wardani, F. (2012). Studi Derivat Ribavirin dan GTP sebagai Inhibitor Untuk NS5 Metiltransferase Virus Denger [Skripsi]. Jakarta : Universitas Indonesia.

Widyanto, F Candra dan Tribowo, C. (2013). Trend Disease : Trend Disease Penyakit Saat Ini. Jakarta : Trans Info Media. 